\title{
Meteorologically generated tsunami-like waves in the North Sea 1-2 July 2015 and 28 May 2008
}

Reports of unusual tidal activity in Stonehaven harbour (Aberdeenshire, Scotland) were received from local harbour officials on 1 July 2015. The scale of disturbances reported was sufficient to affect the passage of harbour traffic, cause damage to boats, and lead to the injury of a crewman. A similar event with unusual tidal movements reported in the North Sea occurred on 28 May 2008 (Harbitz Glimsdal, and Løvholt, 2010). The evidence presented here is that these tidal anomalies were caused by meteorological factors in close proximity to severe convective activity, and formed in a similar way to reports of abnormal waves in the English Channel on 27 June 2011 (as discussed by Tappin et al, 2013, and first proposed by Proudman (1929)). As with the previous event, the evidence suggests that the energy necessary to generate and sustain surface pressure anomalies were derived from vertical motion in association with severe convective cells. Once formed these pressure anomalies moved in the atmosphere as travelling waves, travelling in phase with the convective system at least initially, but with the events of 28 May 2008 it would seem that a formed wave front moved ahead of the source of generation. Although wind shear through the depth of the troposphere may play a part in directing gravity waves, as for instance Šepić, et al. 2015 have suggested, the main movement here seems to be correlated with organised convective cells. However, it is not possible here to fully analyse, investigate and respond to their claims in this paper.

\section{Events of 1 July 2015}

On the evening of 1 July 2015 the sea-level along parts of the east coast of Scotland was reported to have retreated and lowered, and then returned sharply. The size of water level change observed in the entrance to Stonehaven harbour was 1.25 metres (see Figure 1 for map of area).

The following account comes from an email report passed on by Harbourmaster James Brown from Aberdeenshire Council. The harbour at Stonehaven; "...experienced a tidal surge at the harbour last night at 19.30, when the water suddenly started to rush out for about 5 minutes dropping about $1.25 \mathrm{mtrs}$, then after a couple of minutes returned with some force.' Several small vessels were affected by the unexpected changes in tidal flow as water first flowed out of the harbour then returned. Two $40 \mathrm{ft}$ vessels had their rails damaged and stanchion posts pulled out of place as the tide changed. On the Sovereign the foremast was ripped out of its socket by a mooring rope causing a serious head injury to a crewman."

Initial investigations found evidence that a number of tide gauges around Scotland had reported unusual tidal movements. Similar tidal movements were reported by human observers in Gourdon harbour. The tide gauge at Aberdeen showed possible seiche activity from 01/1800UTC with the residual levels varying between about plus $20 \mathrm{~cm}$ and minus $15 \mathrm{~cm}$ from around the mean, based upon 15 minute data (Figure 2). It is also notable that this tidal graph indicates variation on 2 July around 0100-0200UTC and 0700 to 0900 UTC in the overnight period and into the following morning, indicative of further thunderstorm activity (this will be discussed further below). 


\section{Synoptic and radar analysis}

The rain-radar picks-out organised convective systems moving northwards during this period (Figure 3). The main thunderstorm is visible over the Newcastle area at 01/1500UTC and just east of Aberdeen by 1800UTC. The speed of the convective system is measurable from radar returns and travelled about $140 \mathrm{~nm}$ in 3 hours. This gives a speed of 46 knots, or about 23 metres per second. The wider synoptic pattern shows a southerly flow along the North Sea with cold front to the west and high pressure over Scandinavia (Figure 4).

Analysis from upper air soundings suggests this speed of movement correlates with the wind flow at medium levels. The Nottingham ascent is perhaps the most representative of the development location of this thundery cell (Figure 5). It is some distance south of Boulmer and suggests a southerly wind of 35 to 40 knots at the mid level steering flow. This ascent indicates convective cloud bases around 3000 metres, and this is supported by Lasar Cloud Base Recorders (LCBR) at Dishforth in Yorkshire and later Leuchars in east Scotland (not shown). There was sufficient convectively available potential energy (CAPE) and wind shear to organise and drive the storm system with lower wet-bulb potential temperature $\left(\theta_{w}\right)$ at mid-levels offering potential instability. This development was confirmed by reports of large hail and frequent lighting across eastern parts of the UK, and occurred following a hot July day (see paper by Lewis and Young, 2016).

An automatically generated estimation of CAPE from the Nottingham ascent data (by the Wyoming data base) is given as $462 \mathrm{Jkg}^{-1}$, together with a Bulk Richardson Number (BRN) of 11.5 (BRN: effectively CAPE/(Vertical Shear) ${ }^{2}$ ). However, these values probably need some modification to account for the elevated cloud base. There is also evidential directional shear. If the Normands Point structure is modified to nearer the cloud base of 3000 metres (the Lifting Condensation Level), the CAPE value may be manually estimated to be in excess of twice that given (see Lewis and Young, 2016). These values are sufficient to allow for the possibility of supercell or mesoscale convective system development (MCS), with a corresponding surface low or trough evidenced in the pressure pattern. The presence of rapidly rising air in an organised convective system can then lead to a lowering of surface pressure and a small, identifiable low centre that may develop near the middle of the cell.

There is also sufficient potential energy for strong downdrafts (DCAPE), which may account for surface pressure rises ahead of a convective cell. A rough estimation from the Nottingham ascent suggests DCAPE values of $1000-1100 \mathrm{Jkg}^{-1}$, if taken from $400 \mathrm{mbar}$ to the surface. With this event the atmospheric conditions were set-up for the possibility of energy transfer into the sea surface through initial air pressure rises, followed by falls, as the system moved from land to sea. The speed of movement of the convective system was sufficient to drive a convectively generated surface pressure wave forwards with an evident travelling surface pressure wave recorded by surface observations.

Although there is evidence of wind gusts from downdrafts at the surface ahead of the convective cells these are not especially strong. Leeming in Yorkshire reported a gust of 32 knots in the hour to 1500UTC, and this is supported by evidence from Doppler Radar (see Lewis and Young, 2016). The Fawbush-Miller Technique suggests possible downdrafts of 45 knots, and simply turning the DCAPE value (from above) into a speed would give a 
downdraft of around 90 knots (where $V \max =\sqrt{ }(2 x D C A P E)$, although due to de-acceleration and outflow at the surface this value may be approximately halved to 45 knots.

There is evidence of pressure fluctuations of several millibars at a number of observation sites in northeast England, east Scotland and the North Sea, which correlate with the passage of the storm system. Hourly pressure readings are available for several North Sea platforms, but for land-based observations readings are available on a per-minute basis. At Boulmer, the reported QFF MSL pressure initially rose from 1012.0 mbar at 1452 UTC to 1013.3 mbar at 1515 UTC. It then fell to 1009.8 mbar by 1552 UTC (in 37 minutes) as the thundery cell passed overhead, and then recovered to 1012.0 mbar by 1616 UTC (Figure 6). Pressure anomalies are less obvious at Dyce (Aberdeen Airport) and Inverbervie, but then the thundery convective cell did not pass directly overhead. However, platforms in the North Sea, to the northeast of Aberdeen, show larger hourly surface air pressure anomalies with the passage of the thundery storm cells (Figure 7). Per-minute data is not available for these observation sites.

Site 62111 (Golden Eye) $58.00 \mathrm{~N} 0.18 \mathrm{~W}$ reported a rise of $1.3 \mathrm{mbar}$ to $1017.0 \mathrm{mbar}$ in the hour to 1800UTC, followed by a fall of $1.6 \mathrm{mbar}$ to $1015.4 \mathrm{mbar}$ in the subsequent hour.

Site 63059 (Buzzard) $57.48 \mathrm{~N}$ 0.54W reported a rise of 0.9 mbar to $1014.8 \mathrm{mbar}$ in the hour to 1800UTC, followed by a fall of $2.1 \mathrm{mbar}$ to $1012.7 \mathrm{mbar}$ in the subsequent hour.

It is evident then that pressure anomalies were observed near or ahead of the travelling convective cells, thus showing that it is likely that there was a convectively-generated surface pressure wave travelling northwards. The speed of movement was approximately 46 knots and correlated with the time that sea level changes were reported along the coast. This supports the belief that meteorological factors were responsible for generating and maintaining a tsunami-like wave in the North Sea.

As noted above, it is of further interest that other pressure anomalies can be seen early the next morning (2 July) with a large pressure jump followed by a rapid fall at Inverbervie and Dyce (Aberdeen Airport) (Figure 6 and 7). This tied in with further high-based convective cells that advected northwards. These thundery cells can be seen on rain radar (Figure 8).

At Inverbervie the pressure rose from $1010.7 \mathrm{mbar}$ at $02 / 0041 \mathrm{UTC}$ to $1015.3 \mathrm{mbar}$ at 02/0110UTC, a rise of $4.6 \mathrm{mbar}$ in 29 minutes.

At Dyce air pressure rose from $1010.5 \mathrm{mbar}$ at $02 / 0103$ UTC to $1015.3 \mathrm{mbar}$ 02/0127UTC, a rise of $4.8 \mathrm{mbar}$ in 24 minutes.

This rapid pressure change also correlated with tidal movement at the Aberdeen tide gauge, but without the benefit of additional human observations, probably due to the time of night, there is less knowledge about the scale of change on a shorter timescale.

The evidence provided here suggests that reported tsunami-like waves were closely colocated and correlated with medium level convective cells and surface pressure anomalies of the order of 3 to 5 mbar. Indeed the partial surface pressure analysis described here shows 
that the size of pressure jumps is linked quite closely to the proximity of the observing station to the centre of the convective activity. This evidence supports our earlier analysis of tsunami-like waves in the English Channel in June 2011 (Tappin et al, 2013). What we may be able to add is that such convective downdrafts may be advected forwards with the convective systems and lead to a travelling pressure wave of several millbars at the surface. With relatively high CAPE, and appropriate wind shear and veer through the depth of the convective layer, it is possible that downdrafts were directed forwards and constrained in the flow by the well organised convective systems.

\section{Development of sea waves}

These pressure changes, perhaps of the order of several millibars, may only adjust the sea level by 3 to 5 centimetres. However, with resonance between a convectively generated surface air pressure wave, and the sea surface wave, it is believed that larger sea level changes are possible. For this to happen, the speed of the sea wave $c$ needs to travel instep with the speed of the mid-level flow $U$ and surface pressure change anomaly $u$. This can be described by the Froude number, a simple ratio for air-to-sea interaction given as: $\mathrm{Fr}$ $=U / c$, and where $U \approx u$. The speed of the wave generated in the sea, for shallow waves, is given by the formula: $c=\sqrt{ } h g$, where $h$ is the water depth and $g$ is acceleration due to gravity. For resonance (Proudman Resonance) to occur a Froude number approximately between 0.9 and 1.1 is preferable (Šepić, et al. 2015).

Bathymetry in the North Sea, along a line from near Boulmer to just east of Aberdeen, suggests the water depth is around the 50 metre depth level. The 50 metre isobath along the east coast of Scotland is shown in Figure 1. Such a depth would give a wave speed of 22 metres per second. The speed of movement of the convective cell has been measured at around 46 knots, or about 23 metres per second from rainfall radar, and corroborated by upper air soundings. This figure is closely linked with the Froude number range suggested above $(23 / 22=1.045)$. A speed of 23 metres per second would require a water depth of about 54 metres. Although given possible effective Froude numbers ranging between 0.9 and 1.1 wave enhancement may occur with depths between 45 and 65 metres. This suggests that the tidal anomalies in Stonehaven harbour may have been generated by the convective cell together with Proudman Resonance between the air pressure wave and the sea surface wave, followed by seiching as seen on the Aberdeen tide gauge. There was then the potential for strong down-drafts, and this is indicated by a rise in pressure ahead of the convective cells, followed by a fall.

\section{Events of 28 May 2008}

The 1 July 2015 is not the first tsunami-like waves reported recently in the North Sea with some common factors with events of the 28 May 2008. Harbitz, Glimsdal, and Løvholt, (2010) have given a brief discussion of tidal anomalies on this date with reports of a fall in sea level of $40 \mathrm{~cm}$ at 28/1000UTC near Stavanger, at Akrehamn, Karmøy. At Peterhead in northeast Scotland the harbour master reported a sudden outflow of water from the harbour, followed by a sudden return about 10 minutes later around 28/1230UTC. Similar, but smaller, tidal flows were reported at near-by Fraserburgh, although with inconclusive evidence of anomalies elsewhere along the North Sea coast. However, the tide gauge at North Shields on the Tyne estuary (with 15 minute readings) recorded anomalous 
movements of $15 \mathrm{~cm}$ in water level between about 28/0745UTC and 28/0845UTC, near the time of the passage of the radar-observed storm cell. At the Lerwick tide gauge in the Shetland Islands, water levels fluctuated by about $14 \mathrm{~cm}$ between 28/1045 UTC and 28/1145UTC (Figure 9). In the Faeroes, at Hvannasund, unusual waves were reported with amplitude of 3 metres and period of 4 to 6 minutes around 28/1400UTC.

The thundery convective cells can be traced back to a developing low pressure system during the previous day in the Mediterranean Sea. This then spread northwards across France, to southeast England and then the southern North Sea. This strong mid-level flow of very warm, humid air, with speeds 40 to 50 knots, was associated with a deepening low centre over the UK, and came up against a blocking high pressure over Scandinavia to Iceland, which backed the flow to the southeast. Synoptic analyses for this event are shown in Figure 10. Radar imagery shows convective cells moving northwards along and near the North Sea coast associated with a low pressure system and sharp frontal trough, but evidently weakening in intensity (Figure 11). Evidence of significant CAPE was more clearly seen in upper air soundings over Europe with weakening CAPE as the feature moved northwards along the North Sea (not shown).

The sharp pressure trough for this event was picked up by hourly surface observations, with typically a rise of around 1 mbar followed by a fall of 4 to 5 mbars, followed by a partial recovery of 1 to $3 \mathrm{mbar}$ (Figure 12). For instance Bridlington in Yorkshire shows the following readings:

1006.8 mbars at $28 / 0400$ UTC 1008.0 mbars at $28 / 0500$ UTC 1004.1 mbars at $28 / 0600$ UTC 1005.1 mbars at $28 / 0700$ UTC

This pressure anomaly is still evident at Aberdeen but clearly weakening. Further north, at Kirkwall, Fair Isle and Lerwick there is a slightly erratic pressure fall, but only of the order of about 1 mbar per hour (not shown). This is insufficient to account for the local generation of tidal anomalies, suggesting that the long-period wave activity was formed at a distance and travelled across the sea. Unfortunately pressure readings are not available on a per minute basis for this date, which would give greater confidence of this proposal.

So, is it possible to link the tidal movements to the convective cells? There were several bands of showers moving from a southerly direction in the flow. The most active system was observed over East Anglia around 28/0300 UTC, appearing as a line of convection extending across part of the North Sea and moving towards the north-northeast to lie near Edinburgh by 28/0900UTC (Figure 11). The speed of movement near the coast over this period, as measured on the rain radar network, was around 43 knots, which correlates well with measured winds by upper air soundings. The anomalous tide gauge readings at North Shields are synchronised reasonably well with the passage of the active convective cells, although tidal movement reports at Peterhead and Fraserburgh may be running an hour ahead. However, the pressure anomaly was clearly becoming less intense as it moved northwards. Observed tidal movements at Stavanger, Lerwick and Faeroes are possibly a result of formed waves running ahead of the weakening convective cells in deeper water, but confident estimates are difficult due to distance. 
Given a speed of movement of the pressure anomaly in the southern North Sea of 43 knots an ideal water depth of 47 metres would be required for a Froude Number of 1, although with a range from 0.9 to 1.1 the water depth may vary between 39 and 59 metres. Near the coast of East Anglia and the Wash the water is too shallow for Proudman Resonance to occur being only 20 to 30 metres deep. However, there are two areas where an appropriate water depth is encountered. One is off the coast of Yorkshire, and the other is on the western side of the Dogger Bank where water depths vary between 40 and 60 metres (this is shown as the red shaded areas in Figure 13). This may indicate where the tsunami-like wave originated from. A wave may have run northwards along the English-Scottish coast broadly co-located with the convective cells, but over the deeper North Sea a formed wave would ran ahead of the source region. Possible lateral refraction around the Dogger Bank may also have helped to direct a wave towards Norway.

If a wave formed near the Dogger Bank around 28/0600UTC, can it be shown that this was responsible for water levels varying approximately 4 hours later near Stavanger, 5 to 6 hours later at Lerwick and 8 hours later at Hvannasund (as stated by Harbitz, Glimsdal, and Løvholt, (2010))? These locations will be considered in turn in relation to a possible wave front and estimated speed. If a line is drawn from the Dogger Bank to Stavanger the water depth falls to near 75 metres across this part of the North Sea for about 190nm, before crossing the Norwegian Trench at an approximate average depth of 250 metres (see Figure 1). Estimated wave speeds given these parameters would suggest a period of travel of about 4.2 hours, which is sufficiently close to be a contender for the source region for later tidal anomalies on the Norwegian coast near Stavanger at 1000UTC. For Lerwick the depth may be estimated at 100 metres for a distance of $330 \mathrm{~nm}$. This would suggest a time of arrival of 5.3 hours later, or between 1100 and 1200 UTC. However, there remains lack of certainty with these estimates, and it is even more difficult to undertake a similar assessment for Hvannasund in the Faeroe Islands. The distance from Dogger Bank to the Atlantic continental shelf is about $360 \mathrm{~nm}$ at an estimated average depth of 100 metres. The sea floor then falls to around 1000 metres with an estimated average depth of 500 metres over a distance of some $100 \mathrm{~nm}$, before rising steeply near the Faeroes with an estimated average depth of 200 metres over 40nm (See Figure 14). Using these assumptions would give a period of travel of around 7 hours to 1300 UTC, which is approximately an hour earlier than reported tidal anomalies. But bearing in mind these figures are only estimations this suggests sufficiently close correlation to be a contender.

\section{Summary}

With the 1 July 2015 event it is possible to correlate quite closely the tidal movements with the convective systems and surface pressure anomalies. This supports our earlier findings from events on 27 June 2011 in the English Channel that suggest that the generation of meteotsunamis are tied in with strong convective storm cells. However, it is more difficult to adequately correlate events of the 28 May 2008 directly with the convective activity. This is partly due to a poorer data set, but also because waves were reported at some distance to the main areas of convection. While convective activity seems to have had a part to play in tidal movements along North Sea coasts of England and Scotland on this 2008 date, the long-period sea surface wave seems to have moved some distance from the main area of atmospheric forcing. This is possibly because the waves maintained their energy and 
coherence as they travelled, with surface air pressure anomalies not strongly in evidence in the more northern localities of Lerwick and Hvannasund.

These events indicate that meteotsunamis can affect UK coastlines and that the sudden changes in water levels can cause damage including injuries. High resolution data recordings greatly assist post event analysis.

\section{Acknowledgements}

James Brown of Aberdeenshire Council, harbourmaster at Stonehaven, is thanked for bringing the 2015 event to our attention. Also thanks to Martin Young and Matt Lewis for comments on this paper. Tide data from 28 May 2008 has been sourced from the British Oceanographic Data centre (BODC).

\section{References}

Harbitz,C.B., Glimsdal, S and Løvholt, F. 2010. WP8.6 North East Atlantic coastal areas. D8.6: Tsunami run-up heights and flooding along the coasts of the North-East Atlantic and the Norwegian fjords. In: Harbitz, C.B. 2010. EU Transfer project, ICG Contributions, ICG Report 2010-10-1

Lewis M, and Young M. 2016. Weather (paper title and details to be confirmed).

Proudman, J. 1929. The effects on the sea of changes in atmospheric pressure. Geophys. Suppl. Mon. Notices R. Astr. Soc. 2, 197-209.

Šepić, J. Vilibić, I, Rabinovich, AB., Monserrat, S. 2015. Widespread tsunami-like waves of 23-27 June in the Mediterranean and Black Seas generated by high-altitude atmospheric forcing. Sci. Rep. 5, 11682; doi: 10.1038/srep11682.

Tappin, D., Sibley, A., Horsburgh, K., Daubord, C., Cox, D., and Long, D. 2013 The English Channel tsunami of 27 June 2011 - a probable meteorological source. Weather, Vol. 68, No. 6, 144-152.

Figure 1. Map of area affected by the unusual wave activity on 1 July 2015 and 28 May 2008, together with correlation of the $50 \mathrm{~m}$ and $100 \mathrm{~m}$ isobaths with the storm / wave tracks.

Figure 2. Aberdeen residual tide graph 01/0600 to 02/1800 UTC.

Figure 3. Rainfall radar returns indicating the track of the storm cell from near Boulmer to northeast of Aberdeen from 01/1500 to 01/1800 UTC.

Figure 4. Synoptic analysis for 01 July 20151800 UTC and 02 July 20150000 UTC.

Figure 5. Nottingham Ascent 01/1200UTC suggesting high base convective cells and significant CAPE.

Figure 6. Marked surface air pressure changes (mbar) from per-minute data for selected stations on 1 and 2 July 2015. 
Figure 7. Hourly pressure readings (mbar) from North Sea Ships / Platforms - stations 62111 (Golden Eye), 62117 (Buchan), 63059 (Buzzard) 1-2 July 2015.

Figure 8. Rain radar images for 02/0000 UTC to 02/0300UTC.

Figure 9. Small movements in tide gauge data (metres) at Lerwick and North Shields.

Figure 10. Synoptic analysis 28 May 20080000 UTC and 29 May 20080000 UTC

Figure 11. Rain radar images for 280300 to 0900 UTC.

Figure 12. Hourly pressure readings for a selection of stations 28 May 2008 (for locations see map Figure 13).

Figure 13. Map showing location of reported pressure readings with bathymetry $(-20,-40$ and -60 isobaths) and location of the Dogger Bank. The red-shaded areas are places where the Froude Number is sufficient to allow for enhancement given a medium level wind flow of 43 knots.

Figure 14. Bathymetry near the Faeroes Islands and Shetland Islands. 


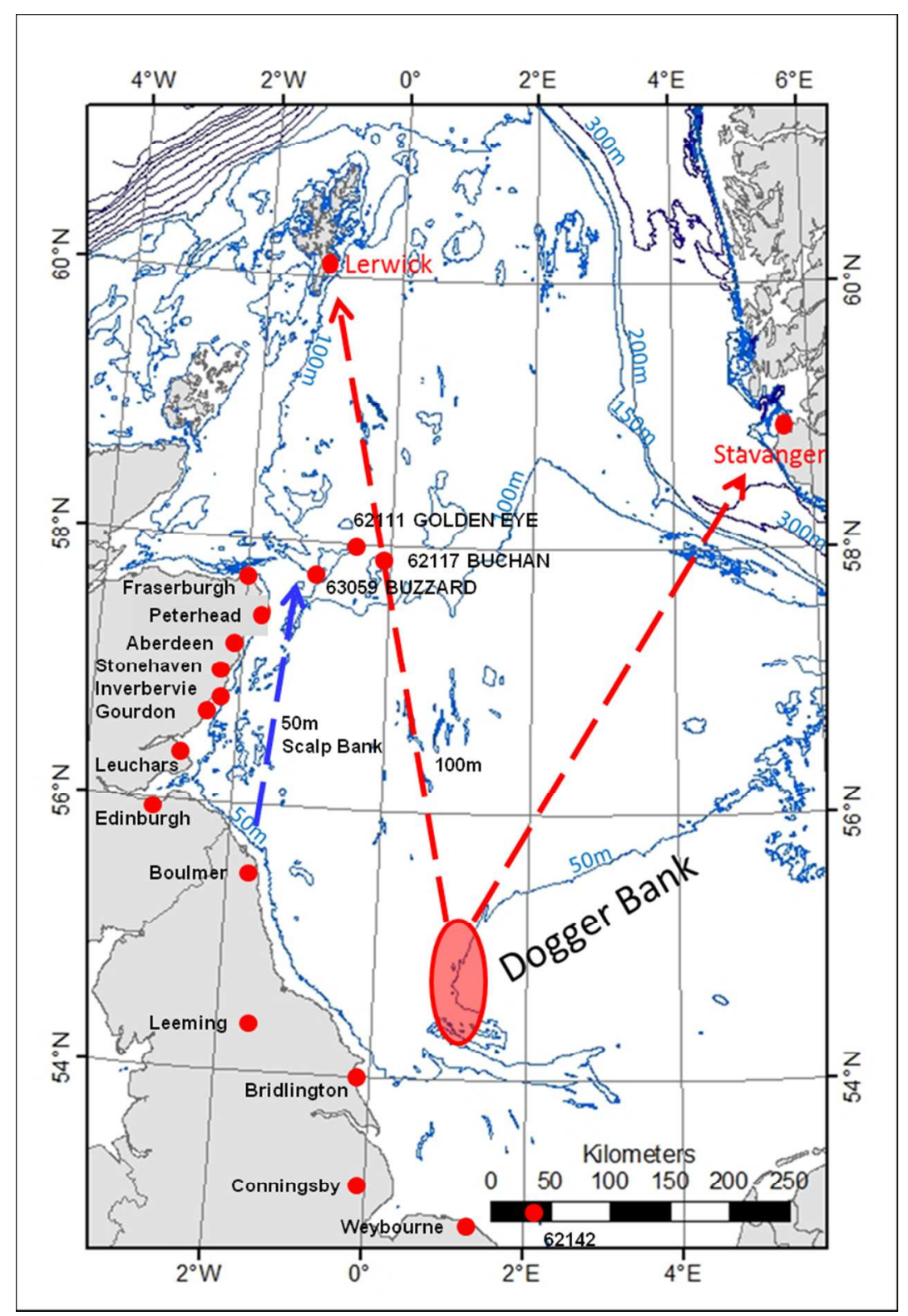

Figure 1. Map of area affected by the unusual wave activity on 1 July 2015 and 28 May 2008, together with correlation of the $50 \mathrm{~m}$ and $100 \mathrm{~m}$ isobaths with the storm / wave tracks. $129 \times 190 \mathrm{~mm}(150 \times 150 \mathrm{DPI})$ 


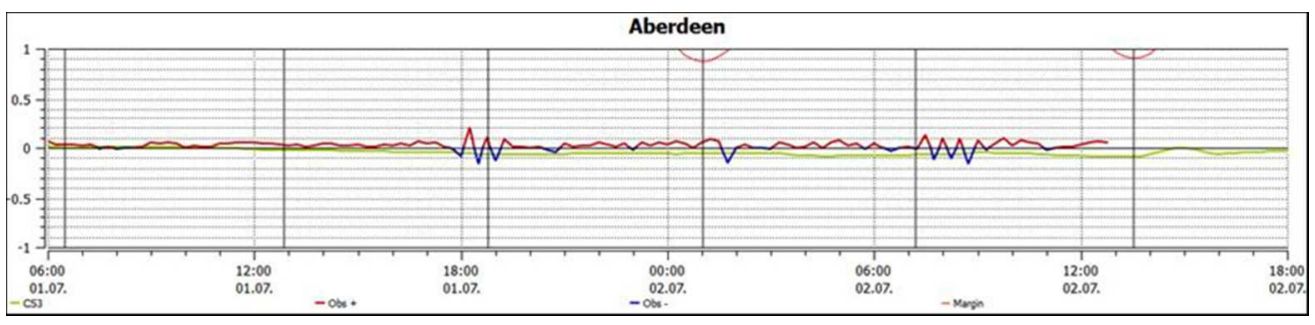

Figure 2 . Aberdeen residual tide graph $01 / 0600$ to $02 / 1800$ UTC. $159 \times 59 \mathrm{~mm}(146 \times 92 \mathrm{DPI})$ 


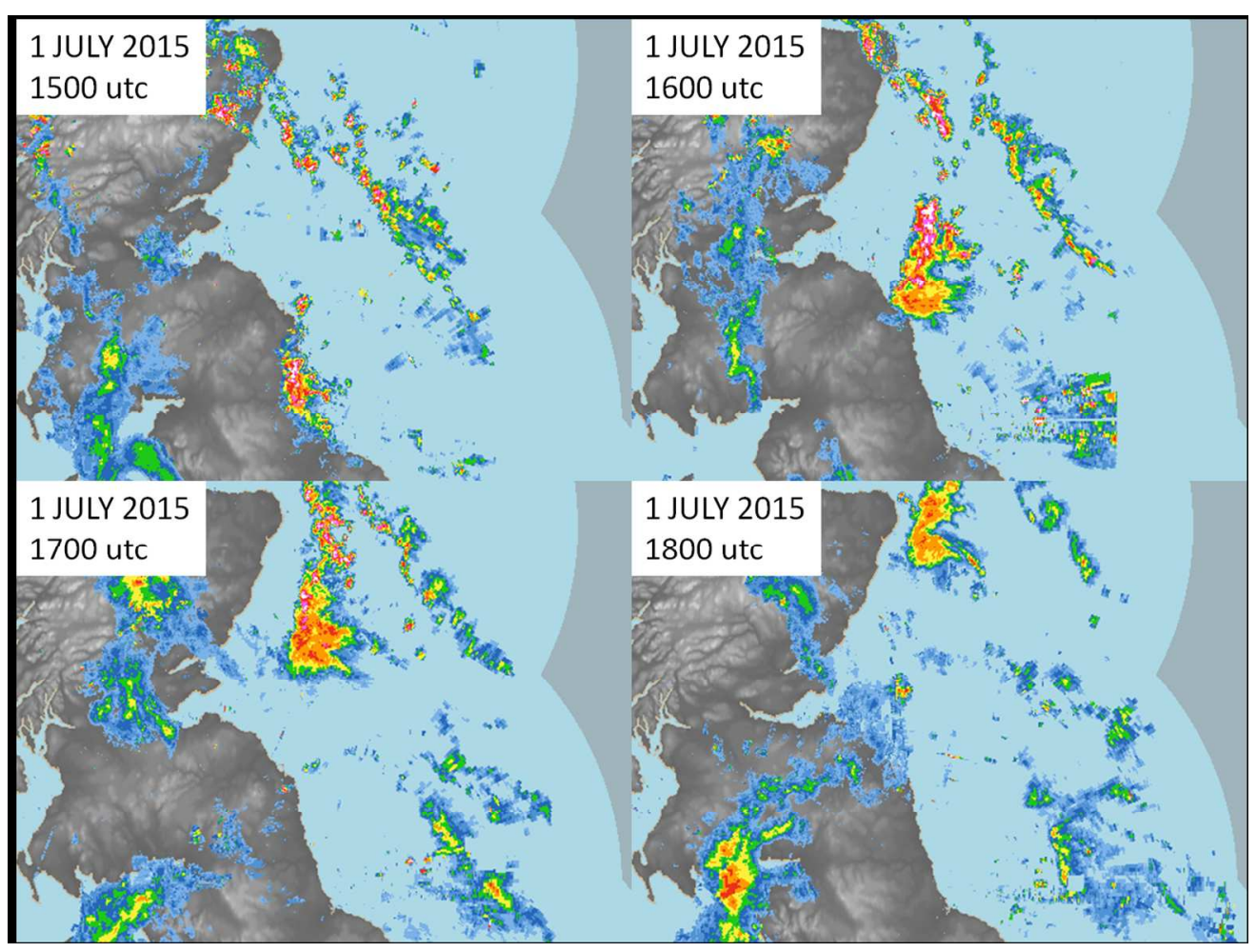

Figure 3. Rainfall radar returns indicating the track of the storm cell from near Boulmer to northeast of Aberdeen from 01/1500 to 01/1800 UTC. $256 \times 191 \mathrm{~mm}(150 \times 150 \mathrm{DPI})$ 


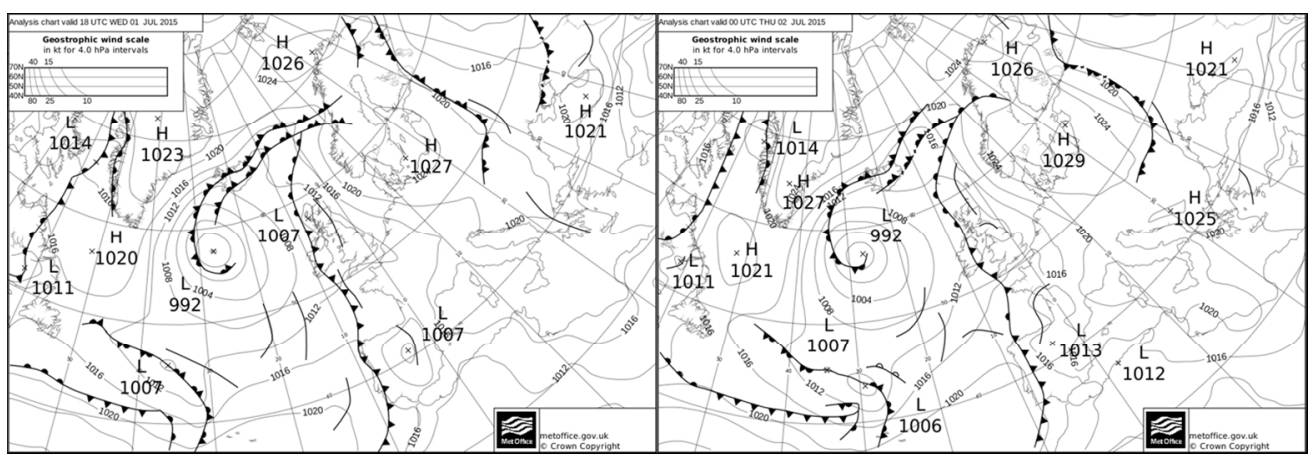

Figure 4. Synoptic analysis for 01 July 20151800 UTC and 02 July 20150000 UTC. $254 \times 86 \mathrm{~mm}(150 \times 150 \mathrm{DPI})$ 


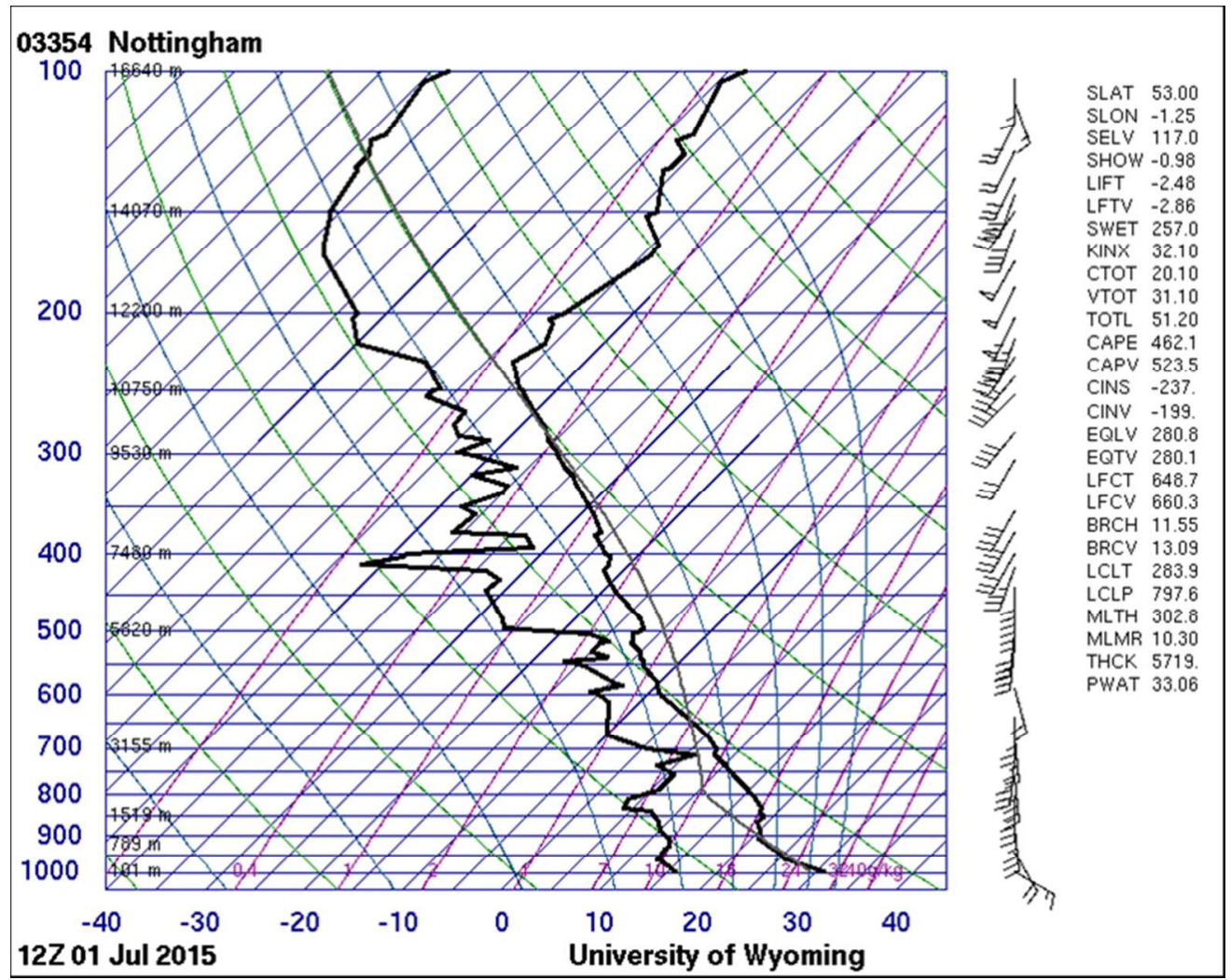

Figure 5. Nottingham Ascent 01/1200UTC suggesting high base convective cells and significant CAPE. $218 \times 184 \mathrm{~mm}(93 \times 88 \mathrm{DPI})$ 
Figure 6. Marked surface air pressure changes (mbar) from per-minute data for selected stations on 1 and 2 July 2015.

$254 \times 122 \mathrm{~mm}(150 \times 150 \mathrm{DPI})$ 


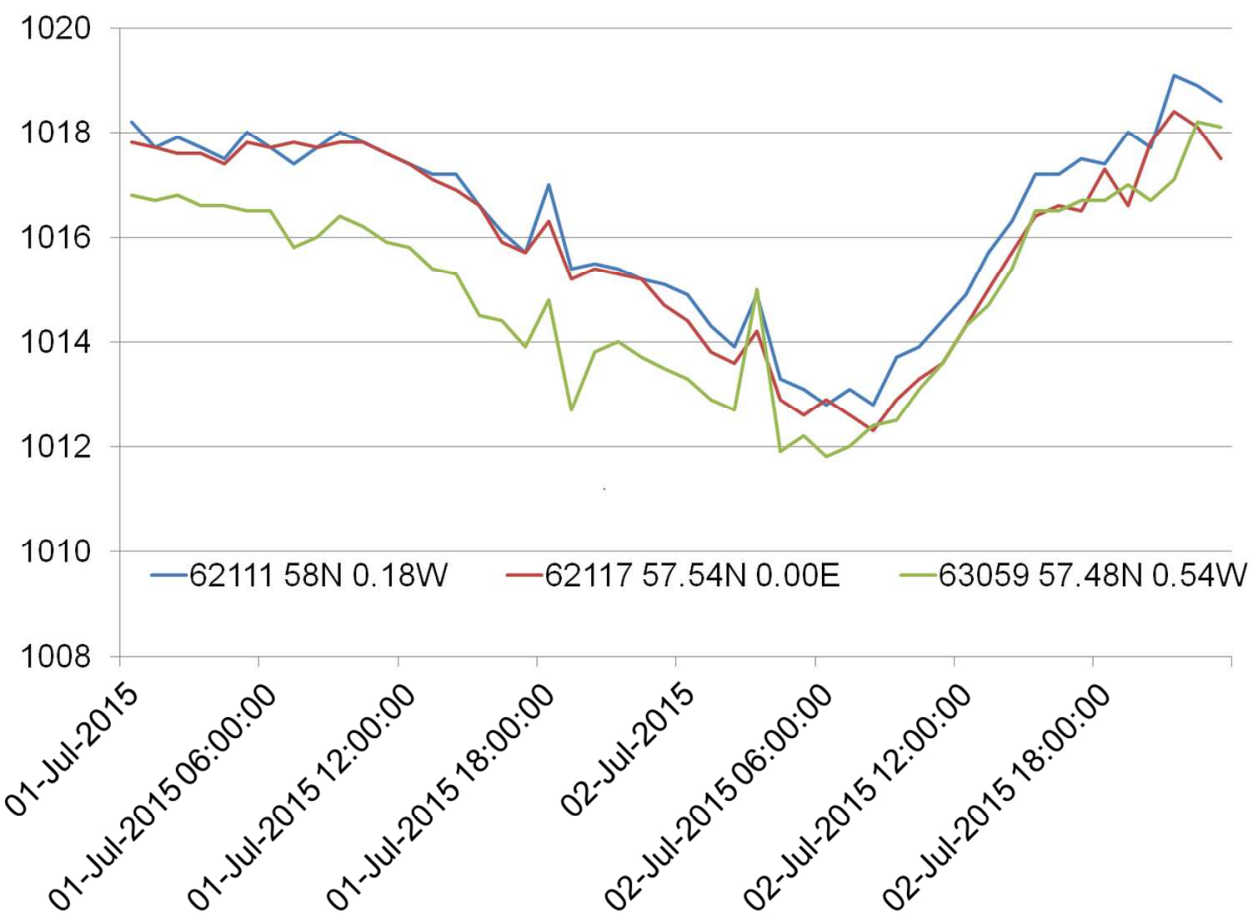

Figure 7. Hourly pressure readings (mbar) from North Sea Ships / Platforms - stations 62111 (Golden Eye), 62117 (Buchan), 63059 (Buzzard) 1-2 July 2015. $254 \times 185 \mathrm{~mm}(150 \times 150 \mathrm{DPI})$ 


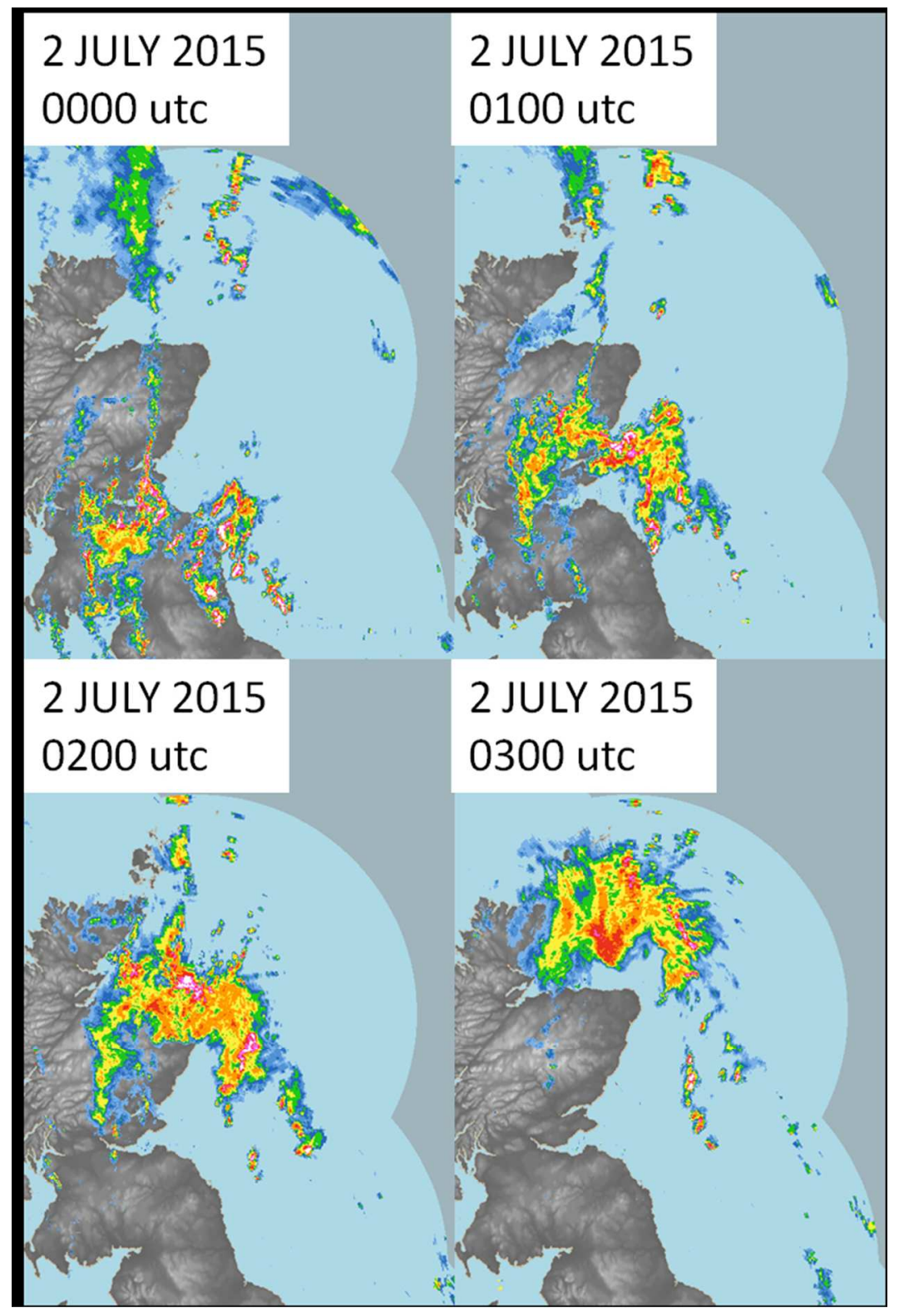

Figure 8. Rain radar images for $02 / 0000$ UTC to 02/0300UTC. $129 \times 191 \mathrm{~mm}(150 \times 150 \mathrm{DPI})$ 
Figure 9. Small movements in tide gauge data (metres) at Lerwick and North Shields 28 May 2008. $254 \times 190 \mathrm{~mm}(150 \times 150 \mathrm{DPI})$ 


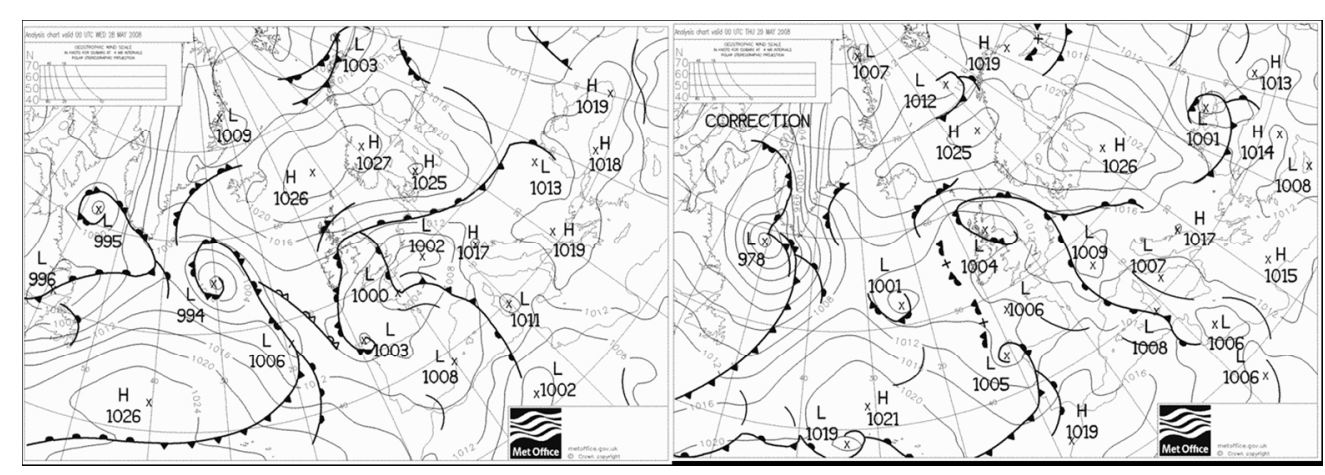

Figure 10. Synoptic analysis 28 May 20080000 UTC and 29 May 20080000 UTC $254 \times 87 \mathrm{~mm}(150 \times 150 \mathrm{DPI})$ 


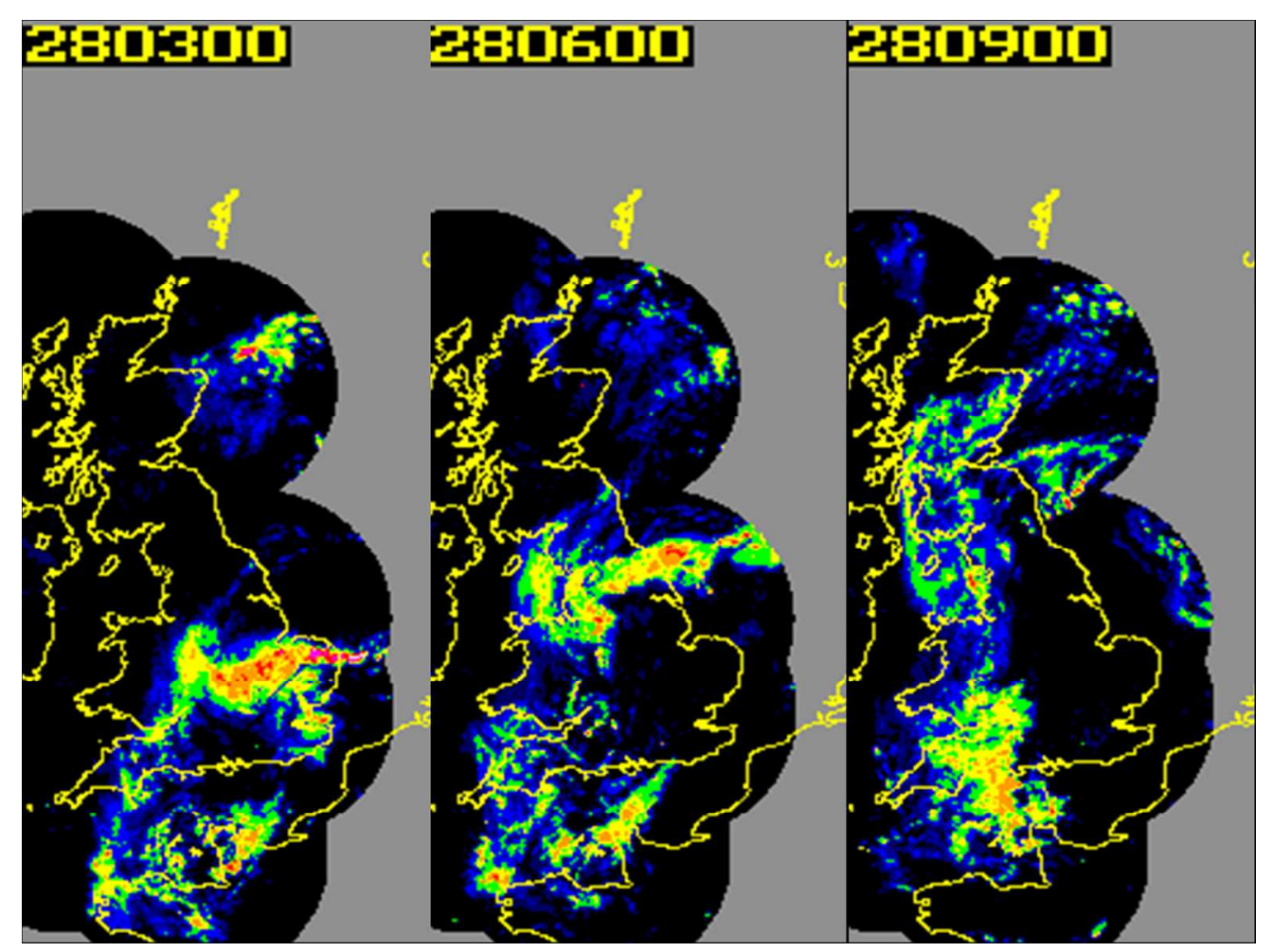

Figure 11. Rain radar images for 280300 to 0900 UTC. $254 \times 190 \mathrm{~mm}(150 \times 150 \mathrm{DPI})$ 


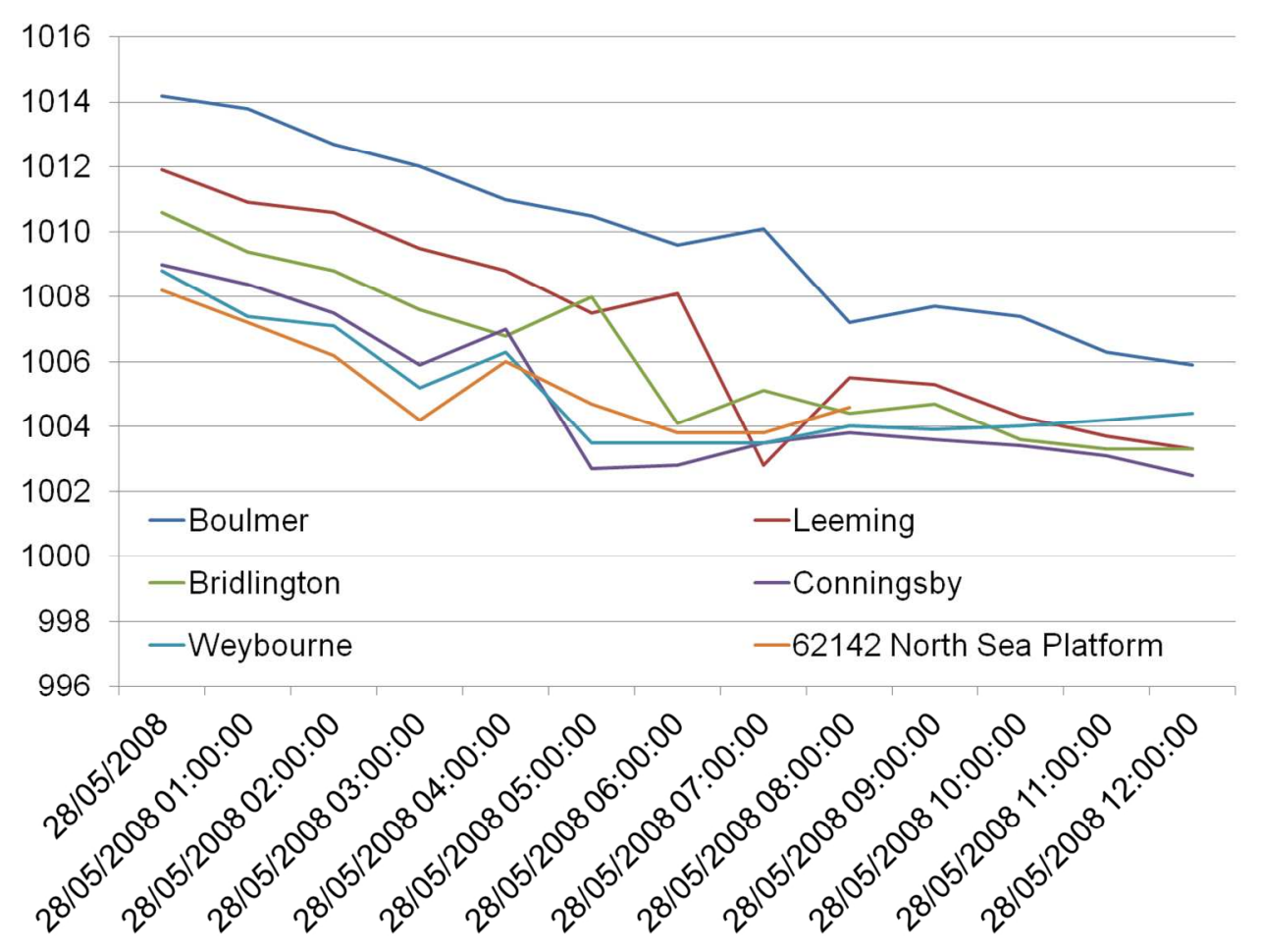

Figure 12. Hourly pressure readings for a selection of stations 28 May 2008 (for locations see map Figure 13). $254 \times 187 \mathrm{~mm}(150 \times 150 \mathrm{DPI})$ 


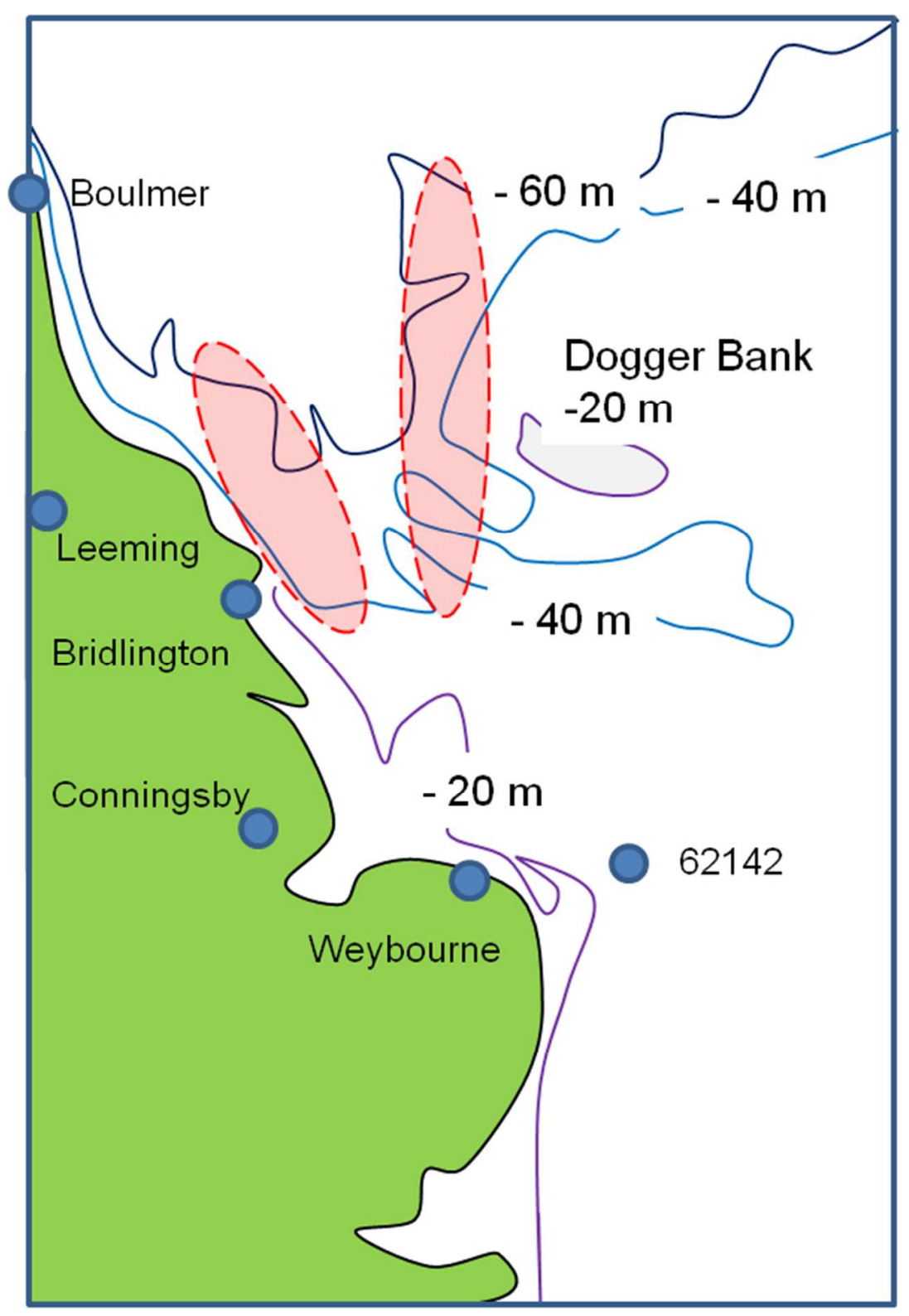

Figure 13. Map showing location of reported pressure readings with bathymetry $(-20,-40$ and -60 isobaths) and location of the Dogger Bank. The red-shaded areas are places where the Froude Number is sufficient to allow for enhancement given a medium level wind flow of 43 knots. $101 \times 146 \mathrm{~mm}(150 \times 150 \mathrm{DPI})$ 


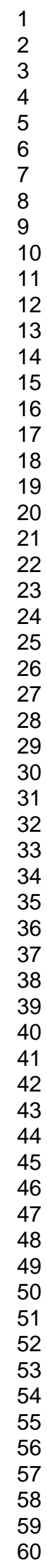

http://mc.manuscriptcentral.com/weather 